\title{
Dampak pemberdayaan masyarakat melalui program biogas dalam mewujudkan kemandirian energi
}

\author{
Friska Indria Nora Harahap \\ Universitas Muhammadiyah Tapanuli Selatan. Jalan St. Mohd. Arif No. 32, Kota \\ Padangsidimpuan, Sumatera Utara 22716, Indonesia \\ Corresponding Author. Email: hrp.frischa@gmail.com \\ Received: 21 February 2018; Revised: 9 March 2018; Accepted: 19 March 2018
}

\begin{abstract}
Abstrak
Tujuan penelitian ini adalah untuk menganalisis dampak pemberdayaan masyarakat melalui biogas dalam mewujudkan kemandirian energi. Penelitian ini menggunakan pendekatan kualitatif yang bertujuan untuk menemukan dan menganalisis secara detail dampak pemberdayaan masyarakat dalam program biogas di Kampung Areng Desa Cibodas. Ada beberapa dampak yang ditemukan dalam pemberdayaan melalui program biogas ini, seperti dampak ekonomi, berkaitan dengan pengehamatan yang dirasakan masyarakat setelah menggunakan biogas, dampak ekologi, yang terlihat dari terjaganya lingkungan sekitar masyarakat yang lebih bersih dan rapi, dan yang ketiga adalah dampak sosial.
\end{abstract}

Kata Kunci: pemberdayaan, dampak pemberdayaan, kemandirian energi

\section{The impact of empowering community through biogas program in manifesting energy independence}

\begin{abstract}
The objective of the study was to analyse the impact of empowering community through biogas in manifesting energy independence. Within the study, qualitative approach was implemented in order to identify and analyse the impacts of empowering community within the biogas program in Kampung Areng, Cibodas Village, in details. Then, there are several impacts that have been found within the community empowerment through the biogas program and these impacts are the economy impact, the ecological impact, and the social impact. The economy impact has been related to the savings that have been resulted from the use of the biogas, while the ecological impact has been related to the maintenance of clean and tidy surrounding environment.
\end{abstract}

Keywords: empowerment, impacts of empowerment, energy independence

How to Cite: Harahap, F. I. N. (2018). Dampak pemberdayaan masyarakat melalui program biogas dalam mewujudkan kemandirian energi.JPPM (Jurnal Pendidikan dan Pemberdayaan Masyarakat), 5(1), 41-5o. doi:http://dx.doi.org/10.21831/jppm.v5i1.18634

doi) http://dx.doi.org/10.21831/jppm.v5i1.18634

\section{PENDAHULUAN}

Pembangunan merupakan upaya yang dilakukan untuk meningkatkan taraf hidup masyarakat di suatu negara. Pembangunan fisik dan ekonomi selalu dianggap menjadi tolak ukur keberhasilan pembangunan. Pengurasan sumber daya alam selalu dianggap menjadi alternatif paling efektif dalam menyelesaikan masalah kemiskinan. Sumber daya alam yang senantiasa dimanfaatkan melebihi daya dukungnya bahkan dirusak tanpa adanya upaya pemulihan akan mengakibatkan kepunahan sumber daya alam, ketidakseimbangan pada ekosistem yang berdampak kepada timbulnya permasalahan-permasalahan baru. 


\section{JPPM (Jurnal Pendidikan dan Pemberdayaan Masyarakat), 5 (1), 2018 - 42}

Friska Indria Nora Harahap

Indonesia merupakan salah satu negara berkembang yang memiliki beragam permasalahan salah satunya adalah kemiskinan. Masalah kemiskinan selalu menjadi perhatian semua pihak untuk dipecahkan, penyebabnya juga bermacam-macam dan begitu juga dengan upaya menanggulanginya. Upaya yang paling awal yang dapat dilakukan untuk menanggulangi kamiskinan adalah dengan mengelola masyarakat untuk memiliki motivasi untuk merubah dan memperbaiki pola hidupnya menjadi masyarakat sejahtera (Riyani, Suherma, \& Nizar, 2010).

Pada dasarnya kemiskinan selalu mengarah kepada tingkat kesejahteraan masyarakat yang rendah. Kemiskinan bukan hanya kekurangan kebutuhan utama (pokok) seperti sandang dan pangan saja, tetapi juga kebutuhan tambahan lainnya seperti pemukiman yang sehat, air bersih, kesehatan, sumber energi, pendidikan, transportasi, rekreasi dan lain-lain. Kaitannya dengan permasalahan kemiskinan adalah ketersediaan dan akses masyarakat terhadap energi. Energi di masyarakat menjadi salah satu sumber kebutuhan yang tidak bisa dipisahkan dalam aktifitas masyarakat, salah satunya adalah untuk memasak dan penerangan. Fakta lapangan terkait ketergantungan energi di masyarakat dapat dilihat berdasarkan data yang disebutkan oleh Yasar et al. (2017) untuk skala dunia, saat ini ada sekitar 1,3 milyar penduduk yang masih mengalami kesulitan akses terhadap listrik, dan sekitar 2,6 milyar penduduk masih bergantung pada bahan bakar tradisional seperti kayu, arang biomassa untuk memasak sehari-hari.

Untuk mengatasi dan memastikan terjangkaunya energi bagi semua. Dunia Internasional juga memiliki fokus dalam hal ketersediaan energi bagi masyarakat. Hal tersebut masuk ke dalam rancangan tujuan pembangunan global atau disebut dengan Sustainable Development Goals (SDGs). Fokus terhadap energi di agenda SDGs yaitu tertuang pada tujuan ke-7, yaitu memastikan akses terhadap energi yang terjangkau,dapat diandalkan,berkelanjutan dan modern bagi semua (Prapti, 2015). Selain itu terkait dengan upaya pemenuhan ketersediaan energi untuk masyarakat juga tertuang dalam
Rancangan Awal Rencana Pembangunan Jangka Menengah Nasional 2015-2019, disebutkan pada Arah Kebijakan dan Strategi Pembangunan salah satunya adalah ketahanan energi, utamanya peningkatan akses masyarakat terhadap energi, peningkatan efisiensi dan bauran energi nasional.

Ketergantungan masyarakat akan energi di pasaran dapat menyebabkan bertambahnya kebutuhan yang harus menjadi bagian dalam pengeluaran belanja oleh masyarakat itu sendiri. Sebagaimana dikemukakan oleh Tumiwa \& Imelda (2011) bahwa penyebab kemiskinan energi adalah masyarakat tidak mampu secara ekonomi untuk mengakses energi (affordability). Sama halnya yang termuat dalam laporan Menteri ESDM (2016) Ignasius Jonan mengatakan bahwa cadangan energi Indonesia yakni minyak sudah hampir habis. Cadangan minyak diperkirakan hanya bisa mencapai 12 tahun dan cadangan gas Indonesia hanya cukup untuk 30 tahun dan cadangan batubara bisa 100 tahun.

Untuk mengatasi permasalahan energi tersebut, maka diperlukan suatu bentuk pemberdayaan baik yang berasal dari pemerintah atau masyarakat itu sendiri yang bertujuan untuk memandirikan masyarakat dibidang pemenuhan kebutuhan energi.

Energi modern dipandang sebagai sebuah inovasi dan elemen kunci distribusi akses energi yang merata kepada seluruh masyarakat, untuk mengurangi kemiskinan dan memungkinkan berdampak kepada pembangunan manusia. Walaupun produksi energi tidak dapat dilakukan dalam jumlah yang besar setidaknya energi yang dihasilkan dapat memenuhi kebutuhan dalam sekala rumah tangga. Salah satunya dengan menggunakan teknologi yang menjanjikan yaitu digester rumah tangga untuk menyediakan biogas untuk memasak dan kebutuhan sehari-hari dengan memanfaatkan energi terbarukan.

Program pemberdayaan masyarakat dalam mengatasi permasalahan keterbatasan energi ini salah satunya diwujudkan dengan program pemanfaatan kotoran hewan ternak untuk dijadikan biogas. Pemanfaatan biogas mampu menyediakan sumber energi alternatif, mengurangi biaya pengeluaran rumah 
JPPM (Jurnal Pendidikan dan Pemberdayaan Masyarakat), 5 (1), 2018 - 43

Friska Indria Nora Harahap

tangga, menekan penggunaan energi bersubsidi dari pemerintah dan melestarikan lingkungaa. Kampung Areng adalah salah satu Kampung yang sudah memanfaatkan kotoran sapi menjadi biogas sebagai energi alternatif.Kampung Areng dengan keberhasilannya meyediakan kebutuhan energi dimasyarakat sampai akhirnya meraih penghargaan Desa Mandiri Energi dan Pangan.

Sejalan dengan pernyataan tersebut, penelitian yang dilakukan oleh Darmawi (2009) yang berjudul Peranan Biogas/Limbah Ternak Sapi Bantuan PT. Petrochina Bagi Peternak di Kabupaten Tanjung Jabung Timur Provinsi Jambi. Dengan hasil penelitian bahwa peranan dari biogas dimanfaatkan sebagai sumber energi rumah tangga seperti elpiji untuk kebutuhan memasak keluarga sehari-hari, penerangan dan menggerakkan generator sehingga dapat dijadikan sumber energi alternatif yang ramah lingkungan dan terbarukan. Dari segi ekonomi biogas telah meringanknan biaya bahan bakar masyarakat $1.177 .125 / \mathrm{kk} /$ thn untuk minyak tanah dan Rp.1.311.237/kk/thn kayu bakar.

Berdasarkan jurnal tersebut bahwa permasalahan kotoran sapi yang meresahkan, menganggu dan mengotori lingkungan selama ini dapat menjadi potensi besar yang dimanfaatkan masyarakat sebagai biogas melalui bantuan fasilitator yang memberikan pendidikan, pemahaman, dan penyadaran yang tujuan untuk meringankan biaya khususnya untuk membeli bahan bakar dan tentunya akan berdampak bagi kesehatan dan kebersihan lingkungan sekitar masyarakat. Keberhasilan yang telah dicapai oleh masyarakat Kampung Areng menjadi daya tarik yang kuat untuk dijadikan suatu bahan penelitian yang dapat mendukung setiap kampung atau desa lain dalam memanfaatkan masalah yaitu kotoran sapi yang dimiliki menjadi berkah yang dapat dimanfaatkan untuk mengurangi beban ekonomi dalam kehidupan sehari-hari. Program biogas ini mampu memandirikan masyarakat kampung areng dalam rangka memenuhi kebutuhan energi. Berdasarkan hal tersebut, penelitian ini akan menganalisis dampak pemberdayaan masyarakat melalui program biogas dalam mewujudkan kemandirian energi.

\section{METODE}

Penelitian ini menggunakan pendekatan kualitatif dengan metode penelitian deskriptif. Pendekatan kualitatif menghasilkan data deskriptif berupa kata-kata tertulis, lisan dari orang-orang dan perilaku yang diamati. Cresswell (2016, p. 4) mengemukakan bahwapendekatan kualitatif bertujuan untuk mengeksplorasi dan memahami yang oleh sejumlah individu atau sekelompok orang yang dianggap berasal dari masalah sosial atau kemanusiaan. Pendapat tersebut sejalan dengan tujuan penelitian untuk menemukan dan menganalisis secara detail dampak pemberdayaan masyarakat melalui program biogas dalam mewujudkan kemandirian energi yang dijelaskan dengan perkataan bukan dengan angka-angka. Metode deskriptif dipilih dalam peneitian ini karena ingin membahas secara rinci sesuai dengan apa yang terjadi dilapangan, dan hasil data yang dihasilkan berupa kata-kata tentang analisis dampak pemberdayaan dalam program biogas di Kampung Areng. Subjek penelitian dalam penelitian ini adalah pihak yang terlibat langsung, memiliki pengetahuan, dapat mengemukakan, menjelaskan, menyatakan, mendemonstrasikan, dan memperlihatkan berbagai kegiatan berkenaan dengan fokus penelitian, dan berjumlah 7 orang. Tempat penelitian dilaksanakan di RW 7 Kampung Areng, Desa Cibodas Kecamatan Lembang Kabupaten Bandung Barat, Provinsi Jawa Barat. Alasan peneliti memilih RW 7 (Kampung Areng) sebagai tempat penelitian karena mayoritas masyarakatnya bekerja sebagai peternak sapi dan masyarakat pengguna Biogas.

\section{HASIL DAN PEMBAHASAN}

Pemberdayaan berarti pemberian kekuasasan atau meningkatkan kekuasaan orang-orang yang dianggap tidak berdaya atau tidak berkuasa. Pemberdayaan masyarakat merupakan salah satu upaya untuk menyelesaikan permasalahan yang dihadapi oleh masyarakat dengan cara memberikan daya kepada masyarakat. Banyak programprogram pemberdayan yang telah dilakukan oleh pemerintah yang arah ataupun tujuannya adalah untuk mengatasi permasalahan 


\section{JPPM (Jurnal Pendidikan dan Pemberdayaan Masyarakat), 5 (1), 2018 - 44}

Friska Indria Nora Harahap

kemiskinan yang dihadapi masyarakat. Kemiskinan merupakan dalam bentuk ekonomi.

\section{Dampak Ekonomi}

Setiap program pemberdayaan harus memberikan dampak kepada sasaran dari pemberdayaan. Dampak ekonomi selalu menjadi acuan utama keberhasilan dari kebanyakan program pemberdayaan. seiring dengan pendapat Suharto (2014) yang mengatakan bahwa keberhasilan pemberdayaan masyarakat dapat dilihat dari keberdayaan mereka yang menyangkut kemampuan ekonomi, kemampuan mengakses manfaat kesejateraan, dan kemampuan cultural dan politis.

Kemudahan Mengakses Sumber-Sumber Ekonomi

Dampak yang paling ingin langsung dirasakan oleh masyarakat dari proses pemberdayaan adanya peningkatan ekonomi. salah satu bentuk dari dampak ekonomi adalah kemudahan masyarakat mengakses sumber-sumber ekonomi. Sumber ekonomi yang ada di dalam masyarakat bisa saja sumber ekonomi alam, sumber ekonomi yang berasal dari manusia, sumber ekonomi buatan manusia dan yang terakhir adalah kepengusahaan atau pihak yang berinisiatif untuk menggabungkan dan mengkoordinir ketiga sumber sebelumnya.

Menurut Suharto (2014) prinsip dari pemberdayaan merupakan melibatkan akses terhadap sumber-sumber dan kemampuan untuk menggunakan sumber-sumber tersebut secara efektif. Sama hal dengan masyarakat Desa Cibodas khususnya Kampung Areng yang sudah merasakan kemudahankemudahan dalam mengakses sumbersumber ekonomi, dan tidak hanya sebatas mengakses sumber-sumber ekonomi tetapi mereka juga sudah menggunakan sumbersumber itu secara tepat guna. Kemudahan yang paling mencolok yang dimiliki oleh masyarakat berupa kemudahan yang diperoleh masyarakat dalam hal kesempatan memperoleh keterampilan ataupun keahlian untuk mengolah sumber ekonomi atau potensi yang dimiliki, dalam hal ini potensi yang dimiliki adalah kotoran sapi yang dulu- nya adalah permasalahan sekarang menjadi lahan pendapatan yang dapat membantu perekonomian keluarga. Sama halnya dengan pendapat Mardikanto \& Soebiato (2015) yang juga mengatakan bahwa penyediaan berbagai masukan (input), serta pembukaan akses ke dalam berbagai peluang (opportunities) yang akan membuat masyarakat menjadi berdaya. Terlihat jelas bahwa pembukaan dan pemberian akses kepada sumbersumber ekonomi akan membantu masyarakat untuk menjadi masyarakat berdaya.

Sejalan dengan pendapat Swift dan Levin dalam Mardikanto \& Soebiato (2015) menyebutkan bahwa masyarakat yang berdaya salah satu ditunjukan dengan ciri masyarakat memiliki akses terhadap sumber-sumber produktif yang memungkinkan mereka dapat meningkatkan pendapatannya dan memperoleh barang-barang dan jasa yang mereka perlukan. Seperti, masayarakat Cibodas dan petugas lapangan untuk program Biogas sangat terbuka untuk menanyakan seputar pengetahuan, keterampilan yang ingin mereka pelajari bahkan masyarakat juga sangat terbantu oleh petugas lapangan yang selalu memberikan bantuan baik peralatan, seperti kompor dan pembangunan digester biogas dan kemudahan dalam hal pembayaran pembuatan biogas dengan cara dicicil, selain itu petugas juga menawarkan jasa berupa garansi perawatan kepada masyarakat selama 3 tahun, dan bukan hanya itu masyarakat juga diberikan keleluasaan untuk dapat berdiskusi dengan pihak Biru sebagai sebagai petugas lapangan berdiskusi seputar permasalah atau kesulitan yang mereka hadapi seputar program biogas ataupun program-program lanjutan lainnya yang ada di Kampung Areng seperti pengolahan pupuk kascing, budidaya cacing dan pembuatan pakan ternak.

Jenis Mata Pencaharian Baru Masyarakat

Pemberdayaan pada hakikatnya upaya untuk mendorong masyarakat untuk berpastisipasi dalam kegiatan yang tujuannya untuk memperbaiki mutu kehidupan masyarakat, baik itu mutu ekonomi, sosial, lingkungan, mental dan lain-lain. Peningkatan ekonomi masyarakat merupakan sesuatu yang menjadi fokus perhatian pembuat 
program ataupun masyarakat yang menjadi sasaran dari program. Pada biasanya ketertarikan masyarakat untuk ikut berpastisipasi dalam program pemberdayaan selain karena minat, dorongan kebutuhan masyarakat terhadap jenis program yang akan dilaksanakan lebih menjadi alasan utama. Kebutuhan masyarakat pada dasarnya tidak jauh dari peningkatan ekonomi, walaupun masih banyak faktor-faktor atau hal-hal lain yang juga dibutuhkan oleh masyarakat.

Peningkatan ekonomi dapat ditandai oleh beberapa hal, seperti peningkatan pendapatan masyarakat dan juga daya beli masyarakat. Tujuan pemberdayaan menurut Mardikanto \& Soebiato (2015) bahwa salah satu dari tujuan pemberdayaan adalah perbaikan pendapatan (better income) yaitu berupa perbaikan bisnis yang dilakukan, diharapkan akan dapat memperbaiki pendapatan yang diperolehnya, termasuk pendapatan keluarga dan masyarakatnya.

Upaya yang dilakukan oleh masyarakat Kampung Areng dalam hal peningkatan pendapatan dengan kemampuan yang telah dimiliki berupa pengetahuan seputar pembuatan dan perawatan digester biogas dan menggunakannya dalam kehidupan seharihari. Dari hasil wawancara dilapangan keuntungan yang diperoleh masyarakat kurang lebih berkisar $90 \%$ beruntung atau dapat menghemat pengeluaran untuk membeli gas elpiji dalam kehidupan sehari-hari dari biasanya. Adapun nominal keuntungan ataupun pengematan yang didapatkan oleh masyarakat dengan menggunakan biogas dapat dilihat dalam Tabel 1.

Tabel 1. Penghematan Pengeluaran Masyarakat Setiap Tahunnya jika Menggunakan Biogas

\begin{tabular}{clc}
\hline No. & \multicolumn{1}{c}{ Nama } & Keuntungan/Tahun \\
\hline 1. & Ibu Eti & Rp. 1.517 .670 \\
2. & Ibu Nina & Rp. 1.139 .895 \\
3. & Bapak Omas & Rp. 1.139.895 \\
4. & Bapak Tateng & Rp. 1.457.080 \\
5. & Teh Nani & Rp. 1.139.895 \\
\hline
\end{tabular}

Sumber: Diolah berdasarkan hasil wawancara di lapangan tahun 2017

Keuntungan sekaligus penghematan yang dapat dirasakan oleh masyarakat dalam hal pengeluaran membeli bahan bakar gas elpiji sangar signifikan. Dengan keuntungan yang diperoleh oleh masyarakat akan berdampak baik terhadap peningkatan perekonomian mereka. Darmawi (2009) mengatakan bahwa biogas telah meringankan pengeluaran masyarakat. Dalam penelitiannya menengaskan bahwa terdapat keuntungan atau penghematan signifikan yang dirasakan oleh masyarakat Jambi sekitar 1.177.125/kk/ tahun untuk minyak tanah dan Rp.1.311.237/ kk/tahun kayu bakar (Darmawi, 2009).

Selain biogas memberikan keuntungan karena bisa menghemat pengeluaran, masyarakat kampung Areng juga melakukan pengembangan dalam hal penciptaan mata pencaharian baru untuk masyarakat. Seperti adanya budidaya cacing yang laku dijual untuk campuran obat-obatan, pakan burung, dan untuk kosmetik. Selain budidaya cacing, pembuaatan pupuk ada juga dihasilkan oleh masyarakat.

Berkenaan dengan keuntungan yang diperoleh oleh masyarakat dengan menggunakan biogas Biyatmoko \& Wijokongko (2011) dalam penelitiannya yang berjudul persepsi masyarakat Kabupaten Banjar terhadap pemanfaatan energi biogas dan kualitas pupuk limbah biogas juga menyebutkan bahwamasyarakat merasakan cukup manfaat dan adanya nilai tambah dengan adanya penggunaan biogas, tidak merasakan adanya kendala berarti pada saat aplikasinya dan cukup senang karena tidak menimbulkan dampak lingkungan yang buruk. Nilai tambah yang dirasakan masyarakat adalah biogas lebih ekonomis dan murah sehingga ketergantungan akan minyak tanah berkurang dan menghemat sekitar 120 ribu/bulannya pengeluaran untuk membeli minyak tanah dapat diminamalisir.

Mardikanto \& Soebiato (2015) yang meyebutkan bahwa pemberdayaan merupakan upaya memenuhi kebutuhan yang diinginkan oleh individu, kelompok, dan masyarakat luas agar mereka memiliki kemampuan untuk melakukan pilihan dan pengontrolan lingkungannya agar dapat memenuhi keinginan-keinginannya, termasuk aksebilitasnya terhadap sumberdaya yang terkait dengan pekerjaannya dan aktivitas sosialnya. Upaya yang dilakukan oleh masyarakat dalam hal memenuhi kebutuhan 
mereka akan pupuk untuk pertanian misalnya, masyarakat yang bekerja sebagai peternak sekarang sudah tidak lagi membeli pupuk kompos kotoran ayam, tetapi masyarakat sudah bisa mencukupi kebutuhan pupuk untuk pertanian pribadi dan sekarang masyarakat juga sudah memasarkan pupuk kascing secara langsung kepada petani yang membutuhkan dan ada juga yang menjual pupuk kascing kepada pengepul.

Menururt Cahyadi (2008) pupuk padat biogas saat ini dapat membantu petani mengurangi penggunaan pupuk anorganik yang harganya terus meningkat, dengan memberikan kualitas hara dan biomassa yang baik bagi tanaman. Kenyataan di lapangan juga membuktikan bahwa harga yang ditawarkan untuk satu karung pupuk kascing lebih mahal dibanding dengan harga satu karung pupuk kotoran ayam. Kualitas yang diberikan oleh pupuk kascing ini lebih bagus dibanding pupuk kotoran ayam.

Dari Tabel 2 dapat kita lihat perbandingan penggunaan pupuk pada pertanian. Terlihat jelas keuntungan yang akan diperoleh masyarakat yang membuat pupuk kascing karena hanya bermodalkan kotoran sapi, keuntungan dapat dirasakan oleh masyarakat secara luas khususnya petani sayuran karena sebagian besar masyarakat di Desa Cibodas, dan masyarakat sekitar merasa terbantu dan bisa menghemat pengeluaran untuk pupuk kompos yang diperoleh oleh masyarakat jika menggunakan pupuk kompos kascing dikarenakan kualitasnya lebih jadi penggunaan pupuk kascing jumlahnya lebih sedikit dibanding dengan menggunakan pupuk kandang dari kotoran ayam.

\section{Dampak Sosial}

Setiap program pemberdayaan yang ada di masyarakat akan menjadikan masyarakat sebagai sasaran utama dari pember- dayaan, seperti tujuan dari pemberdayaan adalah memperbaiki kualitas hidup seluruh masyarakat secara keseluruhan. Tetapi pada kenyataannya tidak semua program pemberdayaan menimbulkan dampak ataupun akibat yang baik dan ada juga ditemui dampak negatif walaupun diketahui bahwa tidak ada satupun program pemberdayaan yang memiliki tujuan buruk. Selain juga dapat dipandang sebagai upaya utuk meningkatkan harkat dan martabat masyarakat, Pranarkan dan Muljarto dalam Anwas (2013) mengatakan bahwa pemberdayaan salah satu upaya untuk membangun eksistensi pribadi, keluarga, masyarakat, bangsa, pemerintah, Negara, dan tata nilai dan beradab yang terwujud di berbagai kehidupan politik, hukum, pendidikan, dan lain sebagainya.

Hal tersebut juga dirasakan oleh masyarakat Kampung Areng, dampak sosial yang paling terasa oleh masyarakat adalah perasaan dihargai, eksistensi yang masyarakat dapatkan, baik secara pribadi maupun masyarakat secara umum dikarenakan mendapat penghargaan Desa Mandiri Energi yang menjadikan desa tersebut sering dijadikan sebagai desa percontohan pengolahan biogas yang berdampak pada banyaknya kunjungan tamu baik dari lembaga pemerintah, ataupun mahasiswa yang ingin belajar kepada masyarakat seputar pembuatan biogas dan pengolahan ampas biogas menjadi olahan pupuk dengan kualitas bagus dan harga yang lebih mahal. Selain itu, ibu-ibu juga merasakan dampak sosial yang menjadikan mereka lebih dihargai oleh pasangannya atau lingkungan sekitar, karena mempunyai pengetahuan, mata pencaharian baru sehingga memudahkan ibu-ibu untuk membeli kebutuhan mereka, misalnya seperti bedak, lipstick, kerudung, dan baju.

Tabel 2. Perbandingan Penggunaan Pupuk Kandang Kotoran Sapi Dengan Pupuk Kascing

\begin{tabular}{cccc}
\hline $\begin{array}{c}\text { Jenis komoditas yang } \\
\text { digunakan }\end{array}$ & $\begin{array}{c}\text { Kebutuhan pupuk untuk 3000 } \\
\text { pohon brokoli }\end{array}$ & Harga/Karung & $\begin{array}{c}\text { Jumlah yang harus } \\
\text { dibayar }\end{array}$ \\
\hline $\begin{array}{c}\text { Pupuk kotoran ayam } \\
\text { Kascing }\end{array}$ & $\begin{array}{c}75 \text { Karung } \\
\text { 25 Karung }\end{array}$ & @ Rp. 10.000 & Rp. 750.000 \\
& Total Keuntungan & Rp. 25.000 & Rp. 625.000 \\
Rp. 125.000 & \\
\hline
\end{tabular}

Sumber: Diolah dari data yang ditemukan di lapangan 
Bekerja Sama dengan Mitra Program dan Beradaptasi dengan Perubahan yang ada di Sekitar

Program pemberdayaan masyarakat tidak akan dikatakan berhasil tanpa adanya partisipasi dari masyarakat. Karena pada hakekatnya pemberdayaan adalah bukan bicara tentang seberapa banyak tujuan pemberdayaan yang dicapai, tetapi pemberdayaan lebih mengarah kepada seberapa besar pastisipasi masyarakat untuk ikut serta dalam proses pemberdayaan. Sejalan dengan Anwas (2013) mengatakan bahwa partisipasi adanya kesadaran untuk berubah dari masyarakat, terjadinya proses belajar menuju kearah perbaikan dan peningkatan kualitas yang lebih baik. Masyarakat Kampung Areng berpartisipasi dalam kegiatan dalam kegiatan seputar biogas dan pengolahan limbah biogas terlihat dari antusiasnya masyarakat untuk mengikuti sosialisasi yang diadakan oleh Biru di salah satu rumah masyarakat.

Pastipasi yang dilakukan oleh masyarakat Kampung Areng tidak dapat begitu saja terjadi, dan tentunya sama dengan kondisi masyarakat pada umumnya yang tidak langsung menerima inovasi atau sesuatu yang baru yang ditawarkan oleh agen pembaharu. Karena menurut masyarakat sesuatu yang dapat dan layak untuk diterima untuk diadopsi adalah sesuatu yang memiliki manfaat yang jelas dan langsung dirasakan oleh masyarakat.

Selain itu penggunaan biogas juga memberikan keuntungan relatif yang dimana manfaat dari biogas jelas memberikan keuntungan ekonomi menurut masyarakat karena tidak akan membeli gas lagi, rendahnya biaya permulaan yang harus dikeluarkan oleh masyarakat karena biaya untuk membangun reaktor disubsidi sama KPSBU dan pembayarannya juga dapat dicicil dengan biaya cicilan yang sangat terjangkau, selain itu masih ada alasan rendahnya resiko yang akan diperoleh oleh masyarakat jika menggunakan biogas dikarenakan mereka menganggap reaktor atau tabung gasnya ada di luar rumah dan di tanam di dalam tanah sehingga menurut masyarakat lebih aman dibanding gas elpiji. Alasan terakhir juga kenapa masyarakat mau mengadopsi inovasi biogas dalah dikarenakan memberikan kenyamanan disekitar lingkungan khusunya lingkungan kadang karena lebih bersih dan teratur dengan menggunakan biogas. dan alasan masyarakat tersebut sejalan dengan pendapat Hanafi (1987) yang mengatakan bahwa sifat inovasi ada 5 dan yang pertama adalah keuntungna relative, dimana keuntungan relative memiliki beberapa sub-dimensi yang berisikan tingkat keuntungan ekonomi, rendahnya biaya permulaan, resiko nyata lebih rendah, kurangnya ketidaknyamanan, hemat tenaga dan waktu, dan adanya imbalan yang segera dapat diperoleh.

\section{Pengembangan Program}

Pengembangan program adalah tindak lanjut yang akan dilakukan terhadap hasil dari program yang telah dilakukan. Dalam hal ini Kampung Areng adalah kampung yang sudah dianggap berhasil melaksanakan program biogas, dan karena keberhasilannya dalam program biogas menjadikan desa tersebut mendapat penghargaan sebagai desa mandiri Energi pada tahun 2014 oleh dinas ESDM.

Menurut Harthana (2010) bahwa ada beberapa tindak lanjut yang diangggap sebagai kunci yang harus dilakukan setelah berhasil mengembangkan Desa Mandiri Energi menjadi Desa Mandiri Ekonomi adalah melalui upaya-upaya sebagai berikut: membangun kesadaran masyarakat lokal tentang potensi diri dan sumber daya mereka, mengembangkan pemahamam harta karun yang terpendam di daerahnya, membangun semangat ketekunan yang berkesinambungan sebagai suatu kekuatan, mendorong kreativitas dan inovasi, mengembangkan produk yang bernilai tambah tinggi, mengamankan route/distribusi penjualan, dan yang terakhir mengembangkan SDM yang berwawasan luas, berbasis jiwa kewirausahan yang tangguh dan kretif.

Pengembangan yang sedang dilakukan oleh masyarakat adalah membudidayakan Lemna $S$ yang menurut penelitian, susu sapi akan meningkat lebih banyak jika mengkonsumsi pakan tersebut. Untuk beberapa upaya lainnya ternyata telah dilaksanakan oleh masyarakat Kampung Areng, contohnya 
pada upaya yang kedua, masyarakat beranggapan bahwa masalah yang selama ini dirasakan yaitu kotoran sapi ternyata sekarang menjadi harta karun bagi masyarakat, kenapa tidak, dari kotoran sapi yang masih basah dan belum diolah yang dulunya sebelum ada biogas hanya laku Rp 250/karungnya, tapi sekarang setelah ada biogas dan terus berkembangnya produk hasil olahan dari kotoran sapi menjadikan harga kotoran sapi yang masih basah atau kotoran sapi yang belum diolah laku menjadi Rp. 1500/karungnya. Kenaikan harga tersebut bukan tidak beralasan, dikarenakan masyarakat yang sudah mengetahui dan sudah membuktikan sediri manfaat dari pupuk hasil ampas biogas, selain harganya mahal dan juga kualitasnya juga lebih bagus dibanding dengan pupuk kandang lainnya. Masyarakat sampai sekarang masih tetap menekuni usaha pembuatan pupuk dan budidaya kascing, dan tidak sampai disitu masyarakat juga sering melakukan percobaan-percobaan dan inovasi yang ingin mereka lakukan seputar perbaikan jumlah hasil dan kualitasnya. Jenis produk hasil pengembangan yang telah dilakukan dan dihasilkan oleh masyarakat dapat dilihat dalam Tabel 3.

Tabel 3. Jenis Produk Pengembangan yang telah Dilakukan Masyarakat

\begin{tabular}{cc}
\hline No. & Jenis Produk \\
\hline 1. & Pupuk kascing \\
2. & Pupuk limbah biogas \\
3. & Cacing \\
4. & Bio slury \\
5. & Lemna sp \\
6. & Pakan ternak \\
\hline
\end{tabular}

Dampak Ekologi

Dampak ekologi dapat dilihat dari bentuk hubungan timbal balik antara manusia dengan kondisi alam sekitanya yaitu lingkungannya.Lingkungan adalah sesuatu yang tidak dapat dipisahkan dari kehidupan manusia. Lingkungan sering menjadi sasaran dari keserakahan manusia. Dalam pembangunan yang bertujuan untuk mengatasi kemiskinan dan memberantas pengangguran sering dijadikan modal utama untuk dikembangkan dan dikelola. Lingkungan selalu dianggap sebagai modal yang paling mudah untuk dijadikan sasaran dalam pemenuhan kebutuhan manusia. Hal seperti ini tidak mungkin tidak berdampak buruk kepada kelestarian lingkungan, pemanfaatan sumber daya alam secara besar-besaran, bahkan cenderung merusak sangat berdampak buruk tidak hanya kepada manusia setempat, tetapi juga pada manusia secara global bahkan berdampak buruk juga pada manusia di masa yang akan datang.

Kerusakan-kerusakan yang terjadi tersebut merupakan salah satu ciri dari krisis ekologi. Seperti yang dikatakan Adiwibowo (2007) bahwa krisis ekologi ini merupakan krisis hubungan antar manusia dan kebudayaannya dengan lingkungan hidup tempat mereka berlindung, bermukim, dan mengeksploitasi sumberdaya alam. Permasalahan ekologi sekarang ini sudah tidak lagi menjadi permasalah pemerintah saja tetapi sudah menjadi permasalah keseruhan umat manusia. Segala lapisan elemen-elemen diikutsertakan dan segala upaya dikerahkan untuk mengatasi krisis ekologi tersebut, salah satu cara yang paling utama untuk dilakukan adalah dengan menumbuhkan kesadaran dalam diri setiap individu bahwa lingkungan adalah sesuatu yang harus dilindungi agar tercipta hubungan yang harmonis antara manusia dan lingkungannya.

\section{Kesadaran Memelihara Lingkungan}

Menumbuhkan kesadaran akan kelestarian terhadap lingkungan di masyarakat bukanlah hal yang baru, pihak pemerintah, swasta, LSM bahkan penggiat di bidang lingkungan tidak mau ketinggalan dalam hal mengkampanyekan sadar lingkungan, dan tidak heran setiap progam-program pemberdayaan tidak luput dari konteks berbasis lingkungan.

Menurut Mardikanto \& Soebiato (2015) pemberdayaan adalah proses "penyadaran" baik penyadaran tentang keberdayannya, masalah-masalahnya yang dihadapinya, kebutuhannya untuk memecahkan masalah, peluang-peluang yang dapat dimanfaatkan, serta penyadaran tentang pilihan-pilihan yang terbaik untuk diri sendiri dan masyarakatnya.

Masyarakat Desa Cibodas khususnya Kampung Areng sebelumnya telah banyak 
mendapat sosialisasi berupa penyadaran permasalahan mereka.mungkin selama ini kotoran sapi tidak menjadi permasalahan bagi mereka, karena mungkin sudah terbiasa dengan kondisi lingkungan yang kotor. Tetapi sekarang masyarakat sudah menyadari bahwa kondisi lingkungan harus dijaga kelestariannya. Terlihat dari kesadaran masyarakat untuk tidak membuang kotoran sapi sembarangan karena dikhawatirkan akan mengalir ke sungai dikarenakan kondisi lingkungan Kampung Areng berada di atas sungai yang nantinya akan merusak sungai baik dari segi warna atapun bau dari air sungai. Selain itu masyarakat juga menyadari bahwa kotoran sapi tidak baik untuk kesehatan, selain menganggu pemandangan dan keasrian lingkungan, kotoran sapi juga menimbulkan polusi udara.

Inisiatif Masyarakat untuk Menjaga

Lingkungannya

Menurut penelitian Ristianasari, Muljono, \& Gani (2013) mengatakan dampak dari pemberdayaan itu ada tiga jenis yaitu ekologi, ekonomi dan sosial budaya. Selain itu dalam penelitiannya juga menyebutkan bahwa dengan adanya pengetahuan, persepsi dan sikap yang baik akan memunculkan tindakan yang sesuai yaitu adanya inisiatif yang muncul dari masyarakat sendiri untuk menjaga lingkungannya. Inisitif untuk menjaga lingkungan sudah dilakukan oleh masyarakat Kampung Areng. Inisiatif dari masyarakat untuk membersihkan dan menjaga lingkungan tidak muncul begitu saja. Ada beberapa hal yang juga memengaruhinya salah satunya adalah pengetahuan masyarakat terhadap manfaat yang akan mereka dapatkan jika mereka menjaga lingkungan. Sekarang kondisi lingkungan mereka sangat jauh berbeda, dulu sebelum masyarakat menggunakan biogas setiap hujan masyarakat akan menjumpai lumpur kotoran sapi di sekitar kandang bahkan di sekitar pekarangan rumah, dan akan banyak ditemuai lalat berterbangan. Kondisi kandang yang tidak terawat juga menjadikan masyarakat dengan sendirinya merasa biasa dengan hal tersebut.

Dengan adanya inisiatif masyarakat mereka bisa memutuskan sendiri hal apa yang harus mereka lakukan berkaitan dengan menjaga lingkungan, dengan menggunakan biogas yang berdampak baik untuk lingkungan, dimana tidak ada lagi lumpur kotoran sapi jika musim hujan dikarenakan sekarang kotoran sapi sudah diolah menjadi biogas dan hasil akhir dari biogas menjadi pupuk kascing, dan tidak ada lagi lalat dan bau yang menyengat dikarenakan hasil dari ampas biogas tidak akan berbau dikarenakan gas yang menimbulkan bau dari kotoran sapi sudah menjadi biogas. Sekarang masyarakat juga sudah tidak mengambil kayu bakar ke hutan milik perhutani karena sudah ada biogas dan masyarakat menyadari jika tetap menebang pohon milik perhutani akan berdampak buruk bagi diri sendiri seperti dijatuhi hukuman karena merusak hutan pemerintah dan berdampak buruk juga bagi semua masyarakat karena akan dikhawatirkan akan menimbulak longsor.

\section{SIMPULAN}

Dampak dari program biogas yang diperoleh berdasarkan hasil penelitian yang dilakukan di masyarakat Kampung Areng adalah kemandirian energi itu sendiri, yang dimana kemandirian ini ditandai dengan tiga dimensi seperti yang pertama adalah dampak ekonomi, yang kedua adalah dampak sosial dan yang terakhir dampak ekologi. Pada dampak ekonomi sangat menonjol dampak yang dirasakan oleh masyarakat dikarenakan pengurangan pengeluaran masyarakat dalam membeli gas elpiji yang mencapai kurang lebih Rp. 1. 100.00o, dan bertambahnya penghasilan masyarakat dari mata pencaharian baru seperti pengolahan pupuk limbah biogas. Dampak sosial yang terlihat diperoleh masyarakat adalah kemampuan masyarakat bekerja sama dengan mitra program terlihat dari hubungan baik masyarakat sampai sekarang dan rasa dihargai dan diperlukan dikarenakan banyaknya pengunjung baik dari pemerintahan yang menjadikan Kampung Areng sebagai desa percontohan untuk biogas dan para akademisi untuk meneliti seputar pengembangan di bidang biogas tersebut. Dampak ekologi yang diperoleh berupa kondisi kandang yang rapi, lingkungan sekitar yang terjaga akan kotoran sapi, karena tidak ada lagi kotoran 
sapi yang menumpuk yang berakibat lumpur kotoran sapi dimana-mana.

\section{DAFTAR PUSTAKA}

Adiwibowo, S. (2007). Etika lingkungan. Bogor.

Anwas, O. M. (2013). Pemberdayaan masyarakat di era global. Bandung: Alfabeta.

Biyatmoko, D., \& Wijokongko, B. (2011). Persepsi masyarakat kabupaten banjar terhadap pemanfaatan energi biogas dan kualitas pupuk limbah biogas. EnviroScienteae, 7(1), 1-5.

Cahyadi, C. (2008). Pemanfaatan limbah kotoran ternak. Jakarta: PT Gramedia Pustaka Utama.

Cresswell, J. (2016). Research design: Pendekatan metode kualitatif, kuantitatif, dan campuran (Edisi 4). Yogyakarta: Pustaka Pelajar.

Darmawi, D. (2009). Peranan biogas limbah ternak sapi bantuan PT. Petrochina bagi peternak di Kabupaten Tanjung Jabung Timur Provinsi Jambi. Jurnal Ilmiah Ilmu-Ilmu Peternakan, XII(4), 191-195. Retrieved from https://onlinejournal.unja.ac.id/index.php/jiip/articl e/view/168

Hanafi, A. (1987). Memasyarakatkan ide-ide baru. Usaha Nasional.

Harthana, M. D. (2010). Upaya pengembangan desa mandiri energi dan ekonomi, melalui pengembangan SDM kreatif dan inovatif berbasis iptek. In Seminar Nasional FMIPA-UT.

Mardikanto, T., \& Soebiato, P. (2015). Pemberdayaan masyarakat dalam perspektif kebijakan publik. Bandung: Alfabeta.

Prapti, R. H. E. (2015). Kertas kajian SRHR dan agenda 2030: Memposisikan SRHR di seluruh bidang pembangunan. Jakarta: Rutgers WPF Indonesia.

Ristianasari, R., Muljono, P., \& Gani, D. S. (2013). Dampak program pemberdayaan model desa konservasi terhadap kemandirian masyarakat: Kasus di taman nasional Bukit Barisan Selatan Lampung. Jurnal Penelitian Sosial Dan Ekonomi Kehutanan, 10(3), 173-185.

https://doi.org/10.20886/jpsek.2013.10. 3.173-185

Riyani, Y., Suherma, L., \& Nizar, N. (2010). Analisis pengaruh program pengentasan kemiskinan dalam upaya menghasilkan suatu model pengentasan kemiskinan yang berkelanjutan (Studi eksperimen pada Dusun Wonodadi Desa Sei. Bulan Kabupaten Kubu Raya Provinsi Kalimantan Barat). Jurnal Aplikasi Manajemen, 8(2), 318-324. Retrieved from

http://jurnaljam.ub.ac.id/index.php/ja $\mathrm{m} /$ article/view/330

Suharto, E. (2010). Membangun masyarakat memberdayakan rakyat. Bandung.

Tumiwa, F., \& Imelda, H. (2011). Kemiskinan energi: Fakta-fakta yang ada di masyarakat. Institute for Essential Services Reform (IESR).

Yasar, A., Nazir, S., Tabinda, A. B., Nazar, M., Rasheed, R., \& Afzaal, M. (2017). Socioeconomic, health and agriculture benefits of rural household biogas plants in energy scarce developing countries: A case study from Pakistan. Renewable Energy, 108, 19-25. https://doi.org/10.1016/J.RENENE.2017. 02.044 